\title{
SPIS TREŚCI / CONTENTS / ОГЛАВЛЕНИЕ
}

\section{ARTYKUŁY / ARTICLES / СTATbИ}

Anton in a Kozyrska, Wyzwania w sferze wyznaniowej w koncepcji bezpieczeństwa narodowego Ukrainy po rewolucji godności

Paulina Maria Nowicka, Zagrożenia bezpieczeństwa zdrowotnego

Ukrainy

Aliyev Shirinbey Hajiali Oghlu, Islam in North-Western Azerbaijan in the Early Medieval Ages

Sadir Mammadov, The Armenia - Azerbaijan Nagorno-Karabakh Conflict and New Threats to the International Security Architecture in the Modern Period: Challenges and Responses

Ksenia Kakareko, Prawo autorskie w państwach Azji Środkowej

Joanna Dzwończyk, Specyfika guanxi - pozytywny czy negatywny kapitat społeczny?

Mich ał Dahl, Sprawozdanie z cyklu spotkań z serii „Orient Express”, Toruń, $2017 r$. 
Kamila Rezmer, Report from the $5^{\text {th }}$ International Asian Congress and the XII International Conference "The direction of Asia, diversity, dialogue on the $100^{\text {th }}$ anniversary of Poland's independence and Azerbaijan independence", Toruń, Poland, 9-11 May 2018

Paulina Kruszyńska, Potęga Chin i edukacja w różnych ujęciach - sprawozdanie $z$ obrad $z$ wybranych paneli $V$ Międzynarodowego Kongresu Azjatyckiego, Toruń, 9-11 maja 2018 r.

Julia Kołodziejska, Białoruś $w$ stosunkach międzynarodowych [recenzja książki Rola i znaczenie Republiki Białoruś we wspótczesnej Europie]

Adam Hołub, Wielowymiarowość wspótczesnej wojny - starcie hegemona z odradzającym się państwem. Rosja versus Ukraina [recenzja książi Wojna hybrydowa Rosji przeciwko Ukrainie]

Ka mil Pietrasik, Wydarzenia sportowe, które zmienia oblicza obszaru postsowieckiego i przyniosa chwałę [recenzja książki Mega events in post-Soviet Eurasia: shifting borderlines of inclusion and exclusion]

B erenika Czerwińska, Kraj kwitnacej wiśni w 9 odsłonach [recenzja książki Japonia widziana z polskiej perspektywy] 